

Emiko Ochiai and Barbara Molony (Eds.)

\title{
Asia's New Mothers: Crafting Gender Roles and Childcare Networks in East and Southeast Asian Societies
}

2008, Global Oriantal, ISBN978-1-905246-37-3, £50.00

\section{村 田泰子}

本書は, 落合恵美子らの研究グループが，2000 年以降, 東・東南アジアの諸社会で行った, 家族 とジェンダーに関する共同研究の成果をまとめた あのである。本書に先立って, 『アジアの家族と ジェンダー』(2007 年) ほかの著作が出版されて いるが，今回，英語で出版されるに当たって，日 本語特有の言い回しや現象などについて多くの説 明が加えられた。したがって本書は単なる翻訳と してではなく，まったく新しい一冊として読まれ てよい。

個人的に, 6 年半前, 落合が専任教員として, 京都大学に赴任してきた当時のことが思い出され る。落合は, 家族を研究するに当たって, 英語で 論文を書くこと，拈よび〈アジア〉との比較にこ だわっていた。世界に向かって発信するために， 論文が英語で書かれなければならないことはよく 承知していたつありだが，あう一方の〈アジア〉 ということについて, わたしを含め, 大方の院生 は理解するのに時間がかかっただろう。なぜなら 当時, 家族やジェンダーについての研究は, 西欧 の研究者が打ち立てた枠組みに依拠して, 西欧と の比較においてなされるのが一般的であり, そこ においてアジアは, 西欧近代という普遍を強調す るための, 都合のよい〈他者〉でしかなかったか らである。そのことと関連して, アジアの家族研 究が伝統家族研究に偏り, 二つ以上の地域にまた がる研究が少ないことも, アジアとの比較を難し

くさせていた。

そうしたなか, 本書は, 〈主婦化 (housewifization)〉というよく知られた概念を軸に, アジアの 複数の社会で同時にフィールドワークを行い, 現 代アジアの家族が共通して経験しているつぎのよ

むらた やすこ：関西学院大学
うな变化を明らかにした。すなわち, 従来の研究 では，主婦化ならびに脱主婦化という変化は，基 本的に西欧近代に限定的なむのとみなされてきた が (日本は数少ない例外とされる), 90 年代以降, 「アジアの奇跡」と呼ばれる奇跡的な経済発展を 遂げた国々でも，主婦化は確実に進んでいる。そ れと同時に，アジアにおける主婦化は，一方では グローバルな世界経済に, 他方でローカルな諸要 素一社会体制や人口学的状況, ジェンダーなど— に条件づけられながら，内部に多様な差異をはら んで進行しているのである。

本書は九つの章からなる。第 1 章で問いと方法 を明確にしたうえで, 第 2 章で「ジェンダー役 割」と「子育てネットワーク」という二つの概念 を軸に, 全体の調査結果が包括的に示される。第 3 から 8 章は個別的社会についての分析で，第 9 章はバーバラ・マローニによる総括である。中国 のように，母親以上に祖父母がよく子育てをする 社会がある一方で, シンガポールのように家事使 用人が活躍する社会あある。それらと比較して, 日本は, 子育てのための社会的ネットワークが乏 しく，母親に負担が集中する社会であり，そのこ とが日本社会における脱主婦化の進行を遅らせて いるという指摘屯なされている。

本書によって，アジアのなかの経済的にもっと あ成功した階層の家族とジェンダーについて, 多 くのことが明らかになっただろう。つぎに望まれ るのは, アイデンティティについての研究, なら びにより周縁化された家族やジェンダーについて の研究である。たとえば, 本書にも登場した, フィリピンやインドネシア出身の家事使用人の若 い女性たちは, 日々何にあこがれ, 何に悩みつつ, 〈家族〉としての実践に参与しているのだろうか。 本書につづく研究が待たれる。 